\title{
STRATEGI MENGATASI KETERGANTUNGAN PEMERINTAH DAERAH KABUPATEN KONAWE UTARA TERHADAP DANA PERIMBANGAN PUSAT
}

\author{
Oleh: \\ La Ode Agus Said ${ }^{1}$ \\ ${ }^{1,}$ Dosen Fakultas Ilmu Sosial dan Ilmu Politik Universitas Halu Oleo \\ agus.odhe20@gmail.com
}

\begin{abstract}
The purpose of this paper is to strategy to overcome the level of dependence of regional governments on the balance funds in Konawe Utara District and analyze the level of dependence of the North Konawe District government on balance funds. The research method used is a qualitative research method using descriptive analysis method. Through this process it is expected to emerge a new hypothetical proposition through the interpretation of interactions between attributes and propositions which are then used to construct categories and provide explanations of the phenomena under study. Data collection techniques are in-depth interviews and document studies. Based on the results of the study, the strategy of the North Konawe District Government in managing the level of dependence on balancing funds in supporting the Regional Expenditure Budget was carried out with 2 (two) patterns: 1) Intensification, namely the North Konawe District Government to optimize Local Revenue by optimizing existing regional tax sources and regional levies; 2) Extensification is to control the level of dependence on balance funds by increasing the revenue of the District of North Konawe by placing more emphasis on expanding new sources of income, namely by developing retribution on fees from the development of market services, parking fees and other fees. The level of regional dependence on balancing funds consisting of Revenue Sharing Funds, General Allocation Funds and Special Allocation Funds is 78.90\%, which indicates that the balancing funds contribute significantly to the district's income Konawe Utara. This means that the level of dependence of regional governments on balancing funds is still quite high, which can be reduced by optimizing other sources of income.
\end{abstract}

\section{Keywords: Strategy, Local Government, Balancing Fund}

\section{PENDAHULUAN}

Undang-Undang No. 33 Tahun 2004 tentang Perimbangan Keuangan Pusat dan Daerah mengatur sumber keuangan Pemerintah Daerah sebagai standar teknis pembagian subsidi pusat kepada Daerah. Pada prinsipnya pembagian sumber keuangan menurut Undang-Undang ini menganut asas pemisahan terikat terhadap sumber keuangan, dimana objek pajak yang dikenakan oleh Pemerintah Pusat tidak dapat dikenakan lagi oleh Pemerintah Daerah sehingga sistem pembagian keuangan antara pemerintah pusat dan daerah di Indonesia menganut asas pemisahan terikat pembagian sumber penerimaan antara Pusat, Provinsi dan Kabupaten/ Kota. Sumber-sumber penerimaan daerah menurut Undang-Undang ini adalah: (1) hasil pajak daerah, (2) hasil retribusi daerah, (3) hasil pengolahan kekayaan daerah yang dipisahkan, (4) lain-lain PAD yang sah, (5) Dana perimbangan, (6) lain-lain pendapatan daerah yang sah. Dana perimbangan yang dimaksud pada poin 5 (lima) adalah Dana Bagi Hasil (DBH), Dana Alokasi Umum (DAU) dan Dana Alokasi Khusus (DAK).

Secara khusus jenis-jenis pajak daerah diatur dalam Undang-Undang mengenai Pajak Daerah dan Retribusi Daerah yang terakhir adalah Undang Undang No. 28 Tahun 2009. Dana Bagi Hasil (DBH) adalah dana yang 
bersumber dari pendapatan APBN dan dibagihasilkan kepada daerah berdasarkan angka persentase tertentu. Dana Bagi Hasil berasal dari pendapatan Pajak maupun pendapatan sumber daya alam. Sumber DBH dari pajak berasal dari Pajak Penghasilan (PPh) pasal 25 dan pasal 29 Wajib Pajak orang pribadi dan PPh pasal 21. Pajak Bumi dan Bangunan serta Bea Perolehan Hak atas Tanah dan Bangunan telah diserahkan kepada daerah berdasarkan Undang-Undang No. 28 Tahun 2009 tentang Pajak Daerah dan Retribusi Daerah. Sedangkan DBH yang berasal dari sumber daya alam meliputi kehutanan, pertambangan umum, perikanan, pertambangan minyak dan gas bumi, dan pertambangan panas bumi. Dana Alokasi Umum (DAU) bertujuan sebagai instrumen pemerataan kemampuan keuangan antara daerah. Hal ini dimaksudkan untuk mengurangi kesenjangan kemampuan daerah melalui penerapan formula yang mempertimbangkan kebutuhan dan potensi daerah. DAU ditentukan berdasarkan besar kecilnya celah fiskal suatu daerah yang merupakan selisih antara kebutuhan daerah dengan potensi daerah. Undang-Undang No. 33 Tahun 2004 mengatur mengenai formula celah fiskal dan penambagan variabel DAU. Daerah yang potensi fiskalnya besar tetapi memiliki kebutuhan fiskal yang kecil akan memperoleh DAU relatif kecil. Sedangkan daerah yang potensi fiskalnya kecil tetapi kebutuhan fiskalnya besar akan memperoleh alokasi DAU yang besar. Sedangkan Dana Alokasi Khusus (DAK) dimaksudkan untuk membiayai kegiatan-kegiatan khusus di daerah tertentu yang merupakan urusan daerah dan sesuai dengan prioritas nasional, khususnya untuk membiayai kebutuhan sarana dan prasarana pelayanan dasar masyarakat yang belum mencapai standar tertentu atau untuk mendorong percepatan pembangunan daerah.

Kriteria DAK meliputi kriteria umum, kriteria khusus dan kriteria teknis yang ditetapkan oleh pemerintah. Kriteria umum berdasarkan pertimbangan kemampuan keuangan daerah dalam APBD, sedangkan kriteria khusus ditetapkan dengan memperhatikan peraturan perundang-undangan dan karakteristik daerah. Kriteria teknis ditetapkan oleh kementerian/departemen teknis terkait. Penerimaan negara terbesar dari Pajak Penghasilan, Pajak Pertambahan Nilai, Pajak Barang Mewah, dan Pajak Penjualan menjadi sumber penerimaan pemerintah Pusat. Provinsi memiliki sumber penerimaan dari sektor pajak berupa Pajak Kendaraan Bermotor, Bea Balik Nama Kendaraan Bermotor, dan Pajak Bahan Bakar Kendaraan Bermotor, Pajak Air Permukaan dan Pajak Rokok. Jenis pajak Daerah Kabupaten dan Kota terdiri dari Pajak Hotel dan Restoran, Pajak Hiburan, Pajak Reklame, Pajak Penerangan Jalan, Pajak Mineral Bukan Logam dan Batuan, Pajak Parkir, Pajak Air Tanah, Pajak Sarang Burung Walet, Pajak Bumi dan Bangunan Perdesaan dan Perkotaan, dan Bea Perolehan Hak atas Tanah dan Bangunan. Pajak Bumi dan Bangunan yang semula menjadi pajak Pusat, berdasarkan Undang-Undang No. 28 Tahun 2009 Tentang Pajak Daerah dan Retribusi Daerah sudah diserahkan kepada Kabupaten/Kota, sehingga PBB merupakan salah satu pajak yang memilik potensi yang baik sebagai sumber penerimaan daerah. Demikian pula Bea Perolehan Hak atas Tanah dan Bangunan juga sudah diserahkan kepada Kabupaten/Kota.

Kabupaten Konawe Utara merupakan daerah otonom yang juga melakukan reformasi tata pemerintahan menuju penyelanggaraan tata pemerintahan yang baik (good governance) tetapi dalam kenyataannya reformasi tersebut juga menghadapi banyak kendala. Salah satu ukuran kemampuan daerah untuk melaksanakan otonomi adalah dengan melihat besarnya nilai PAD yang dapat dicapai oleh daerah tersebut. Dengan PAD yang relatif kecil akan sulit bagi daerah tersebut untuk melaksanakan proses penyelenggaraan pemerintahan dan pembangunan secara mandiri, tanpa didukung oleh pihak lain (dalam hal ini Pemerintah Pusat dan Provinsi). Padahal dalam pelaksanaan otonomi ini, daerah dituntut untuk mampu membiayai dirinya sendiri. Dinas Pendapatan Daerah Kabupaten Konawe Utara adalah instansi teknis di daerah yang menyelenggarakan teknis pembinaan, pengembangan, pengelolaan dan peningkatan Pendapatan, Keuangan dan Aset Daerah pendapatan asli daerah (PAD) yang melayani terhadap perusahaan atau organisasi serta individu, yang ada diwilayahnya. Sementara itu, Produk Domestik Regional Bruto (PDRB) Berdasarkan Lapangan Usaha Kabupaten Konawe 
Vol.1 No.4. Januari 2019. pp.43-57. Copyright@2019. PUBLICUHO Faculty of Social and Political Sciences Halu Oleo University, Kendari, Southeast Sulawesi, Indonesia. e-ISSN: 2621-1351. Open Access at:

http://ojs.uho.ac.id/index.php/PUBLICUHO

(C) Jounal publiuho is licensed under a Creative Commons Attribution 4.0 International License, which permits
unrestricted use, distribution, and reproduction in any medium, provided the original work is properly cited.

Utara sebagai daerah otonom yang baru di bentuk berdasarkan Undang-Undang Nomor 13 Tahun 2007, bila dilihat dari PDRB diperoleh bahwa Sektor perdagangan dari tahun 2014-2018 mengalami peningkatan dari tahun ke tahun. Di sisi lain bahwa, pertumbuhan di sektor pendapatan Assli Daerah (PAD) pada tahun 2011 mencapai 19,68\%, hal ini didukung dengan jumlah pelaku usaha ekonomi di Kabupaten Konawe Utara dari tahun ke tahun mengalami pertambahan unit kegiatan usaha. Gambaran perkembangan APBD untuk 6 (enam) tahun anggaran terlihat pada Table 1 .

Tabel 1. Perkembangan APBD untuk Tahun Anggaran 2014-2018

\begin{tabular}{|c|c|r|r|r|c|}
\hline \multirow{2}{*}{ Thn } & \multicolumn{3}{|c|}{ Uraian APBD (Rp) } & \multicolumn{1}{c|}{ Total } & \multirow{2}{*}{$\%$} \\
\cline { 2 - 6 } & PAD & Dana Perimbangan & $\begin{array}{c}\text { Lain-Lain Pendapatan } \\
\text { yang Sah }\end{array}$ & Pendapatan (Rp) & \\
\hline 2014 & $48,192,394,046$ & $423,249,849,874$ & $142,546,598,349$ & $613,988,842,269$ & 18.35 \\
\hline 2015 & $88,043,084,508$ & $369,135,263,909$ & $88,577,231,549$ & $545,755,579,966$ & 16.31 \\
\hline 2016 & $43,377,151,998$ & $445,368,915,418$ & $30,242,979,609$ & $518,989,047,025$ & 15.51 \\
\hline 2017 & $22,927,746,188$ & $529,928,258,200$ & $34,808,617,583$ & $587,664,621,971$ & 17.57 \\
\hline 2018 & $25,540,194,869$ & $557,817,338,907$ & $97,290,952,327$ & $680,648,486,103$ & 20.35 \\
\hline Total & $245,802,450,369$ & $2,674,553,632,408$ & $425,034,763,417$ & $3,345,390,846,194$ & 100 \\
\hline$\%$ & 7.35 & 79.95 & 12.71 & 100,00 & \\
\hline
\end{tabular}

\section{Sumber : Kabupaten Konawe Utara Tahun 2018}

Dari Tabel 1. terlihat bahwa secara keseluruhan PAD Kabupaten Konawe Utara dalam kurun waktu tahun 2014-2018 mengalami fluktuatif namun cenderung meningkat, dimana pada tahun 2014 sebesar 18,35\%, tahun 2015 sebesar 16,31\%, tahun 2016 sebesar 15,51, tahun 2017 sebesar 17.57\%, dan pada tahun 2018 sebesar 20,35\%. Hal ini memberikan gambaran bahwa PAD Kabupaten Konawe Utara mengalami fluktuatif namun cenderung menurun, kondisi ini didukung oleh peran penting dari berbagai sektor baik itu sektor pertambangan, perdagangan, dan koperasi.

Dilihat dari sisi pendapatan, diantara tiga sektor penunjang APBD tersebut di atas menunjukkan bahwa Dana Perimbangan masih mendominasi penerimaan daerah yaitu sebesar 79,95\% dibandingkan dengan PAD dan Lain-Lain Pendapatan yang Sah. Hal ini mengindikasikan masih tingginya ketergantungan fiskal Pemerintah Daerah Kabupaten Konawe Utara terhadap Pemerintah Pusat selama kurun waktu 2014-2018 kendati paket otonomi daerah telah digulirkan. Pada sisi belanja kebutuhan belanja daerah terus mengalami peningkatan dari tahun ke tahun, hal ini merupakan dampak dari kewenangan otonomi daerah dimana pemerintah daerah secara aktif dan lebih leluasa melakukan pembiayaan dalam upaya pengembangan segala bentuk aktifitas progam-program pembangunan di daerah.

Meningkatnya jumlah dana yang dikelola oleh pemerintahan daerah secara agregat sejak tahun 2014 sampai tahun 2018 tersebut mengindikasikan adanya komitmen politik pemerintah pusat terhadap otonomi daerah. Meskipun demikian besarnya jumlah alokasi anggaran belanja daerah mengandung sejumlah persoalan dalam implementasinya. Salah satu hal yang terkait dengan perimbangan keuangan antara pemerintah pusat dan pemerintahan daerah yaitu adanya ketergantungan daerah pada Dana Alokasi Umum untuk pembiayaan penyelenggaraan pemerintahan daerah. Sehubungan dengan hal tersebut maka penulis tertarik melakukan 
kajian dengan judul "Strategi Mengatasi Ketergantungan Pemerintah Daerah Kabupaten Konawe Utara Terhadap Dana Perimbangan Pusat".

\section{TINJAUAN PUSTAKA}

\section{Penelitian Terdahulu.}

1. Edison, (2009), Pengaruh Pendapatan Assli Daerah Terhadap Belanja Daerah Di Kabupaten Toba samosir, Menyimpulkan bahwa secara simultan Pajak daerah, Retribusi daerah dan lain-lain Pendapatan Asli Daerah yang sah berpengaruh positif terhadap Belanja Daerah di Kabupaten Toba samosir Dan secara parsial Pajak daerah, Retribusi Daerah dan lain-lain Pendapatan Asli Daerah yang sah berpengaruh positif terhadap Belanja Daerah di kabupaten Toba Samosir.

2. Lains (1995) meneliti tentang keuangan dan pembangunan daerah di Sumatera Barat. Menurut Lains kemampuan pembiayaan dengan $\mathrm{PAD}$ dalam pelaksanaan pembangunan daerah sangat kecil atau dengan kata lain sebagian besar pembiayaan dasar dibiayai oleh Pemerintah Pusat. Kecilnya proporsi PAD terhadap total penerimaan daerah disebabkan antara lain karena jenis-jenis pajak yang menjadi hak daerah kurang potensial. Lains menyarankan perlu adanya desentralisasi perencanaan dan pelaksanaan pembiayaan serta sistem pajak dengan pemberian wewenang yang lebih besar kepada Pemerintah Daerah.

3. Lee dan Snow (1997) mengungkapkan bahwa apabila Pemerintah Daerah akan menaikkan penerimaan pajak, maka sebaiknya Pemerintah Daerah memperhitungkan kemampuan membayar dari masyarakat di daerah tersebut dengan mempertimbangkan aspek sosial, ekonomi, dan politik.

4. Kuncoro (1995) memfokuskan pengamatannya pada kenyataan rendahnya PAD, sehingga ketergantungan keuangan Pemerintah Daerah sangat tinggi kepada Pemerintah Pusat. Untuk mengurangi beban subsidi Pemerintah Pusat, Kuncoro menganjurkan diberikannya otonomi keuangan daerah yang relatif luas, sehingga daerah mampu menggali sumber-sumber keuangan sendiri dan memanfaatkannya secara optimal.

5. PAU-SE UGM (2000) yang melakukan penelitian di Kabupaten Magelang menyimpulkan bahwa ketergantungan daerah terhadap sumber penerimaan dari sumbangan dan bantuan Pemerintah Pusat dan dari Pemerintah Daerah Propinsi Jawa Tengah masih sangat tinggi. Dalam era otonomi daerah akan semakin sulit mendapatkan sumbangan dan bantuan sehingga perlu biaya untuk meningkatkan pendapatan daerah sendiri, terutama dari pajak daerah dan retribusi daerah.

6. Miller dan Russek (1997) meneliti semua negara bagian di Amerika Serikat mengenai struktur pajak dan pertumbuhan ekonomi, dan menemukan bahwa pajak dapat berpengaruh positif dan negatif terhadap pertumbuhan ekonomi. Implikasinya adalah Pemerintah Pusat maupun Pemerintah Daerah harus dapat mendorong penerimaan melalui pajak dan menggunakannya secara tepat untuk membiayai pengeluaran yang bersifat strategis untuk mendorong pertumbuhan ekonomi.

Perbedaan penelitian ini dengan penelitian sebelumnya adalah terletak pada kajian yang dilakukan yang lebih pada peranan pendapatan asli daerah (PAD), sedangkan dalam penelitian ini lebih memfokuskan pada strategi peningkatan pendapatan asli daerah (PAD), lokasi, waktu, dan alat analisis yang digunakan. Berkaitan dengan hal tersebut, sejauh pengamatan dan pengetahuan peneliti maka dapat dikatakan bahwa penelitian ini belum pernah dilakukan di Kabupaten Konawe Utara Provinsi Sulawesi Tenggara.

\section{Kerangka Pemikiran}

Upaya peningkatan potensi dan realisasi Pendapatan Asli Daerah (PAD) merupakan konsep dinamis atau berkesinambungan karena pada satu pihak, tahap perencanaan dan pengendalian operasional harus mampu meningkatkan kualitas sistem dan prosedur yang ada sehingga total biaya administratif dapat diminimalisir, sementara dilain pihak perencanaan dan pengendalian harus mampu mengidentifikasikan jenis-jenis penerimaan baru yang sesuai dengan perkembangan dinamis perekonomian. 
Dalam pendeteksian potensi keuangan daerah dapat diawali dengan melihat dan menganalisis pungutanpungutan selama ini, dan kemudian dilakukan pemetaan pungutan yang potensial untuk dikembangkan dalam pendekatannya. Strategi peningkatan PAD dapat dilakukan melalui pola intensifikasi dan ekstensifikasi (Halim, 2002:75-76), yaitu:

1. Pola intensifikasi, peningkatan pendapatan dilakukan dengan lebih menekankan pada penerapan nilai atau prinsip-prinsip perpajakan yang baik. Baik itu pada sumber pendapatan yang berupa pajak daerah, retribusi daerah, badan usaha milik daerah, dan usaha-usaha lainnya yang sah.

2. pola ekstensifikasi, peningkatan pendapatan pemerintah daerah dilakukan dengan lebih menekankan pada perluasaan sumber-sumber pendapatan baru. Baik yang berupa pajak daerah dan retribusi daerah, maupun usaha-usaha lainnya yang sah. Kalaupun dilakukan, upaya ekstensifikasi ini hendaknya lebih menekankan pada retribusi daripada yang bersifat pajak.

Untuk lebih jelasnya desain penelitian dapat di lihat pada Gambar 1.

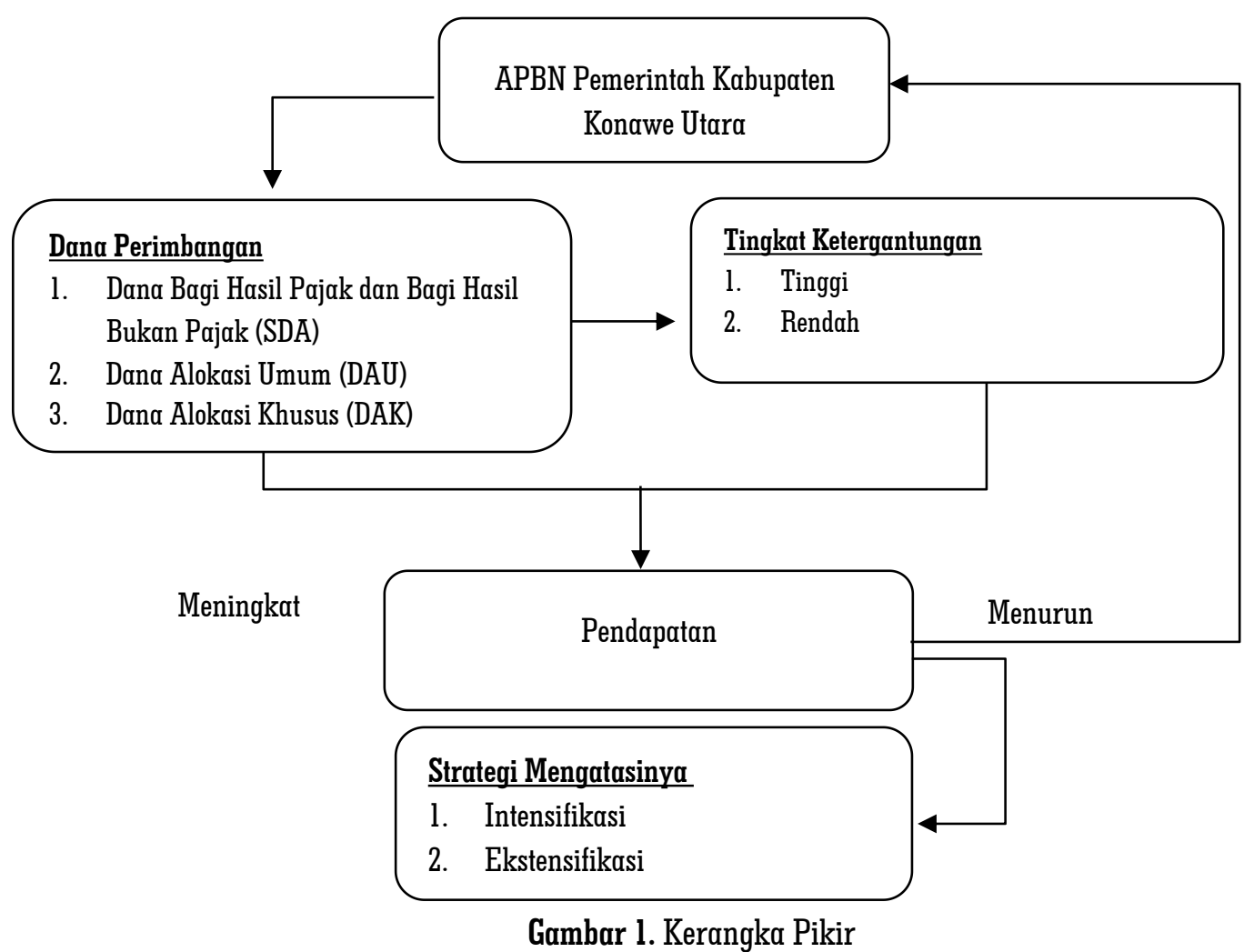

\section{METODE PENELITIAN}

Artikel ini merupakan hasil penelitian yang dilaksanakan di Kabupaten Konawe Utara. Berdasarkan latar belakang, masalah dan tujuan penelitian ini maka menurut penulis yang sesuai dengan metode penelitian ini adalah menggunakan jenis penelitian kualitatif dengan metode analisis deskriptif, Locke, Spriduso dan Silferman (dalam Creswell, 1994:147) mengemukakan bahwa qualitative research is interpretative research. As such, the biases, values and judgement of the researches become stated explicitly in the research report. Such openess is considering to be useful and positive. Penggunaan metode ini adalah untuk mendeskripsikan dan mengkaji secara kualitatif, tingkat ketergantungan pemerintah daerah terhadap dana perimbangan di 
Kabupaten Konawe Utara. Seluruh data diperoleh langsung dari informan dilapangan dengan menggunakan wawancara dan obsevasi.

Melalui pendekatan kualitatif, kajian tentang Strategi mengatasi ketergantungan pemerintah daerah Kabupaten Konawe Utara terhadap dana perimbangan, akan mampu memberikan informasi yang akurat sehingga sangat membantu proses interpretasi informasi dan data yang diperoleh. Melalui proses ini diharapkan muncul proposisi hipotetik baru melalui interpretasi interaksi antara atribut dan propretise yang selanjutnya digunakan untuk membangun kategori dan memberikan eksplanasi terhadap fenomena yang diteliti. Dengan demikian, aktivitas penelitian ini dicirikan oleh kegiatan mengumpulkan, menggambarkan dan menafsirkan data tentang situasi yang dialami, hubungan tertentu, kegiatan, pandangan, sikap yang ditunjukkan atau tentang kecenderungan yang tampak dalam proses yang sedang berlangsung, pertentangan yang meruncing serta kerjasama yang dijalankan. Melalui desain ini dapat diperoleh gambaran fenomena, fakta, sifat serta hubungan fenomenal tentang Strategi mengatasi ketergantungan pemerintah daerah Kabupaten Konawe Utara terhadap dana perimbangan.

\section{Informan Penelitian}

Penentuan informan dalam penelitian ini ditentukan secara purposif. Adapun yang menjadi informan dalam penelitian ini adalah: (1) Bupati, 2) DPRD, 3) Kepala Bapeda, 4) Kepala Dinas Pendapatan Kabupaten Konawe Utara, 5) Kepala Bidang Pendapatan, dan (6) 2 orang staf petugas pemungut PAD Kabupaten Konawe Utara. Dengan demikian maka informan kunci yang terbentuk dalam penelitian ini adalah sebanyak 7 orang.

\section{Teknik Pengumpulan Data}

Tehnik pengumpulan data dalam penelitian ini dengan menggunakan yakni ; wawancara mendalam dan studi dokumen. Menurut Creswell mengemukakan bahwa ada tiga titik utama cara pengumpulan data yakni, (l) partisipasi observer; (2) wawancara; dan (3) telaah dokumen (Creswell,1994:122-123).

\section{Observasi Partisipatif.}

Dengan observasi partisipatif, maka data yang diperoleh akan lebih lengkap, tajam, dan sampai mengetahui pada tingkat makna dari setiap perilaku yang tampak. Susan Stainback dalam Sugiyono (2011:65) menyatakan "in participant observation the researcher observes what people do, listent to what they say, and participates in their activities" maksudnya dalam observasi partisipatif, peneliti mengamati apa yang dikerjakan orang, mendengarkan apa yang mereka ucapkan, dan berpartisipasi dalam aktivitas mereka. Berkaitan dengan observasi ini, peneliti menggunakan metode partisipasi pasif (passive participation), jadi dalam hal ini peneliti datang ditempat kegiatan orang yang diamati, akan tetapi tidak ikut terlibat dalam kegiatan mereka. Partisipasi pasif yang dilakukan oleh peneliti adalah menekankan fokus dari permasalahan yaitu mendengarkan informasi dari informan, kemudian melakukan pengamatan terhadap objek yang diamati.Dalam melakukan pengamatan peneliti tidak menggunakan instrumen yang telah baku, tetapi hanya berupa rambu-rambu pengamatan. Rambu-rambu pengamatan tersebut pengisiannya, namun demikian tidak menutup kemungkinan bagi peneliti untuk mencatat hal-hal yang belum dirumuskan dalam rambu-rambu pengamatan tersebut.

\section{Wawancara}

Wawancara mendalam (In-depth Interview) atau disebut juga wawancara tak terstruktur. Menurut Mulyana (2001:180-181), metode ini bertujuan untuk memperoleh bentuk-bentuk tertentu informasi dari semua informan, tetapi susunan kata dan urutannya disesuaikan dengan ciri-ciri setiap responden tehnik ini bersifat luwes, susunan pertanyaan dan susunan kata-katanya dalam setiap pertanyaan dapat berubah-ubah pada saat wawancara disesuaikan dengan kondisi subyek penelitian (informan). Pada saat peneliti melakukan wawancara, 
peneliti dipandu dengan pedoman wawancara (interviu guide) dan dibantu alat perekan suara (tape recorder), alat pencatat (buku dan pena). Semua informasi dicatat secara teliti dan cermat, dan selalu dikonfirmasi ulang apabila masih ada yang kurang jelas.

\section{Studi Dokumen}

Selain tehnik pengumpulan data tersebut yang peneliti gunakan dalam penelitian ini, peneliti juga menggunakan satu teknik lagi yakni studi dokumen, yaitu melakukan pengumpulan data skunder yang diperlukan untuk menunjang penelitian ini untuk itu dengan studi dokumen peneliti akan mengumpulkan buku, jurnal atau sumber-sumber ilmiah lainnya yang berkaitan dengan strategi Pendapatan Asli Daerah (PAD) Kabupaten Konawe Utara. Kegiatan ini peneliti lakukan berfungsi juga sebagai landasan teoritis untuk memahami fenomena yang perkaitan dengan obyek penelitian ini.

\section{Teknik Analisis Data}

Analisis data adalah proses penyusunan data agar data dalam penelitian dapat ditafsirkan. Menyusun data berarti menggolongkannya dalam pola, tema, atau kategorisasi. Analisis data merupakan proses penyusunan, penyederhanaan data untuk lebih sederhana dan mudah dibaca serta mudah diintegrasikan. Analisis data telah dimulai sejak merumuskannya dan menjelaskan masalah, sebelum terjun kelapangan dan berlangsung terus samapai penulisan hasil penelitian. Menurut Sutopo (1999:82) dalam penelitian kualitatif terdapat tiga komponen utama dalam proses analisis data yakni : (1) reduksi data, (2) penyajian data, dan (3) penarikan kesimpulan ataupun verifikasi. Ketiga proses analisis data tersebut berperan penting dalam proses dan saling berkaitan serta menentukan hasil akhir analisis.

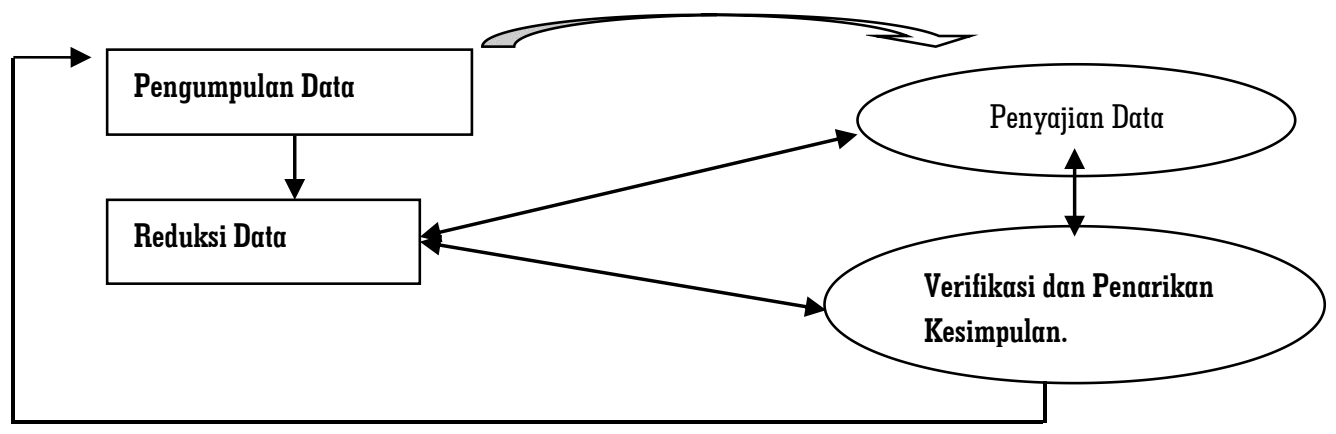

\section{Gambar 2. Teknik Analisis Data Kualitatif. Sumber : Mattew B. Miles dan Michael Huberman, dalam Sutopo (1999:82)}

Kedudukan peneliti sebagai insider, akan memudahkan peneliti dalam mengkategorisasikan dan menerjemahkan makna-makna dari pola perilaku dan informasi yang ada dari suatu masyarakat. sedangkan menurut Nasution (1992:105-124) dalam rangka proses pemeriksaan keabsahan data dilakukan dengan mengacu pada empat hal tersebut yaitu, (l) credibility atau derajat kepercayaan (kredibilitas) tehnik ini menentukan kredibilitas dalam penelitian dengan cara : (a) memperpanjang masa amatan; (b) amatan yang berkesinambungan; (c) Trianggulasi; (d) mendiskusikan dengan berbagai pihak yang berkompoten; (e) menganalisis kasus negatif; memakai referensi; (g) melakukan member check. (2). transferability atau daya keteralihan, konsep ini adalah pengganti konsep validitas eksternal dalam penelitian kuantitatif (3) dependency atau daya ketergantungan. 


\section{PEMBAHASAN}

\section{Tingkat Ketergantungan Daerah Kabupaten Konawe Utara Terhadap Dana Perimbangan Pemerintah Pusat}

Dana Perimbangan, yaitu dana yang bersumber dari dana penerimaan Anggaran Pendapatan dan Belanja Negara (APBN) yang dialokasikan kepada daerah untuk membiayai kebutuhan daerah. Dana perimbangan terdiri dari dana bagi hasil, dana alokasi umum, dan dana alokasi khusus.

Tingkat ketergantungan daerah terhadap dana perimbangan pemerintah pusat dapat ditentukan melalui jumlah Dana Alokasi Umum (DAU) dan Dana Alokasi Khusus (DAK) dibagi total pendapatan daerah. Berikut data konstribusi Dana Perimbangan terhadap pendapatan dalam APBD Kabpuaten Konawe Utara Tahun 2014-2018.

Tabel 2. Kontribusi Dana Perimbangan terhadap Pendapatan dalam APBD

\begin{tabular}{|c|r|r|c|}
\hline Tahun & Dana Perimbangan (Rp) & $\begin{array}{c}\text { Pendapatan dalam APBD } \\
\text { (Rp) }\end{array}$ & $\begin{array}{c}\text { Persentase } \\
\text { Ketergantungan (\%) }\end{array}$ \\
\hline 2014 & $423,249,849,874$ & $613,988,842,269$ & 68.93 \\
\hline 2015 & $369,135,263,909$ & $545,755,579,966$ & 67.64 \\
\hline 2016 & $445,368,915,418$ & $518,989,047,025$ & 85.81 \\
\hline 2017 & $529,928,258,200$ & $587,664,621,971$ & 90.18 \\
\hline 2018 & $557,817,338,907$ & $680,648,486,103$ & 81.95 \\
\hline Total & $2,325,499,626,308$ & $2,947,046,577,334$ & 394.52 \\
\hline Rata-Rata & 387583271051.33 & 491174429555.67 & 78.90 \\
\hline
\end{tabular}

Sumber : Dispenda Kab. Konut (diolah), 2018

Data tersebut di atas menunjukkan bahwa rata-rata tingkat ketergantungan daerah terhadap dana perimbangan adalah sebesar 78,90\%, yang menandakan bahwa dana perimbangan memberikan kontribusi yang cukup tinggi terhadap pendapatan daerah Kabupaten Konawe Utara. Artinya bahwa tingkat ketergantungan pemerintah daerah terhadap dana perimbangan masih cukup tinggi. Hal ini menunjukkan bahwa

1. Pemerintah daerah Kabupaten Konawe Utara belum mampu untuk menjadi daerah otonomi khusus, mengingat tingkat ketergantungan pemerintah daerah terhadap dana perimbangan masih cukup besar yaitu 78,90 \%. Angka tersebut dapat dikurangi dengan mengoptimalkan sumber - sumber pendapatan yang lain.

2. Diperlukan kebijakan pemerintah daerah untuk memaksimalkan sumber - sumber pendapatan daerah untuk mengurangi tingkat ketergantungan daerah terhadap pemerintah pusat.

Hasil analisis menunjukkan bahwa Penerimaan Daerah Kabupaten Konawe Utara selama periode T.A. 2010 s/d 2014 secara signifikan dipengaruhi oleh dana perimbangan (DBH, DAU dan DAK). Untuk DAU dan DBH pengaruhnya relative lebih kecil. Hal ini membuktikan bahwa realisasi penerimaan Daerah dari PAD (terhadap Pajak dan Non Pajak) di Kabupaten Konawe Utara sangat rendah, mengingat penerimaan bagi hasil pajak merupakan bagian daerah yang disalurkan berdasarkan realisasi penerimaan tahun anggaran berjalan (UU. 
Vol.1 No.4. Januari 2019. pp.43-57. Copyright@2019. PUBLICUHO Faculty of Social and Political Sciences Halu Oleo University, Kendari, Southeast Sulawesi, Indonesia. e-ISSN: 2621-1351. Open Access at:

http://ojs.uho.ac.id/index.php/PUBLICUHO

Jounal publiuho is licensed under a Creative Commons Attribution 4.0 International License, which permits unrestricted use, distribution, and reproduction in any medium, provided the original work is properly cited.

No. 33/2004), selain itu realisasi penerimaan DBH di Kabupaten Konawe Utara juga diperoleh dari DBH Non Pajak Misalnya Penerimaan Negara Bukan Pajak dari sektor pertambangan umum terdiri dari iuran eksplorasi dan eksploitasi (royalty) dan iuran tetap (landrent). Kedua iuran tersebut ditetapkan berdasarkan Peraturan Pemerintah Nomor 45 Tahun 2003 tentang Tarif Atas Jenis Penerimaan Negara Bukan Pajak Yang Berlaku Pada Departemen ESDM. Dalam peraturan tersebut, tarif iuran tetap merupakan tarif satuan atas nilai US\$ per luas area eksploitasi/eksplorasi (hektar). Selain itu juga diperoleh dari DBH Non Pajak lainnya yakni Dana Bagi Hasil SDA Kehutanan berasal dari Penerimaan Negara Bukan Pajak dari sektor kehutanan terdiri: (l) Iuran Izin usaha Pemanfaatan Hutan (IIUPH); (2) Provisi Sumber Daya Hutan (PSDH) yang merupakan royalti; dan (3) Dana Reboisasi. Dana Bagi Hasil Sumber Daya Alam Perikanan berasal dari Pungutan Pengusahaan Perikanan (PPP) dan Pungutan Hasil Perikanan (PHP). Pungutan Pengusahaan Perikanan, yaitu pungutan hasil perikanan . berkaitan dengan hal ini, Davey, $(1988,29)$, menjelaskan bahwa keberhasilan dalam mengolah sumber-sumber penerimaan pajak daerah tergantung pada kemampuan pemerintah daerah itu sendiri dalam mengoptimalkan faktor-faktor yang turut menentukan keberhasilan tersebut. Dengan demikian, maka dapat dikatakan bahwa pemerintah daerah Kabupaten Konawe Utara belum mampu mengoptimalkan potensi pajak yang dimilikinya.

Dana Alokasi Umum (DAU) memiliki kontribusi terhadap penerimaan Daerah. Artinya bahwa pengaruh DAU sangat kuat terhadap Penerimaan daerah dan sekaligus menunjukkan kuatnya tingkat ketergantungan APBD Kabupaten Konawe Utara terhadap DAU. Hasil penelitian ini didukung oleh hasil penelitian Yulian Rinawaty dkk (2009) yang menganalisis pengaruh dana perimbangan terhadap pertumbuhan ekonomi di daerah provinsi Sulawesi Tengah, menemukan bahwa dana perimbangan secara keseluruhan yang melibatkan komponenkomponenya yaitu antara lain DAU, DAK, DBH berpengaruh positif dan signifikan mempengaruhi pertumbuhan ekonomi melalui investasi swasta.

Sementara untuk daerah pemekaran sejak dimulainya implementasi otonomi daerah dan desentralisasi fiskal di Indonesia telah memberikan warna baru dengan adanya pemekaran daerah baik di tingkat provinsi serta ter utama di tingkat kabupaten/ kota. Pemekaran daerah memberi serta dampak terutama terhadap jumlah DAU yang diterima oleh daerah pemekaran. Pembagian DAU pada daerah yang mengalami pemekaran dialokasikan pada daerah induk sebelum pemekaran, dan dibagi secara proporsional dengan menggunakan 3 variabel luas wilayah, jumlah penduduk, dan jumlah PNS Daerah. Di sisi belanja, Belanja Pegawai yang merupakan komponen terbesar pengeluaran daerah terus mengalami kenaikan.

Dana Alokasi Khusus (DAK) juga turut memberikan kondtribusi terhadap Penerimaan Daerah. Hal ini didukung oleh kebijakan umum pemerintah pusat dan pemerintah daerah yakni Penentuan alokasi DAK dilakukan melalui 2 tahapan, yaitu (1) penentuan daerah tertentu yang menerima DAK dan (2) penentuan alokasi DAK untuk masing-masing daerah. Penentuan daerah tertentu didasarkan atas tiga kriteria yang dilakukan secara berjenjang, yaitu Pertama; Kriteria Umum (KU), yang ditentukan berdasarkan kemampuan keuangan daerah (indeks fiskal neto) yang dicerminkan dari penerimaan umum APBD setelah dikurangi belanja Pegawai Negeri Sipil di daerah. Penerimaan umum APBD terdiri dari PAD, DAU, dan DBH kecuali DBH yang penggunaannya diarahkan (earmarking). Daerah dengan KU dibawah rata-rata KU secara Nasional adalah daerah yang menjadi prioritas mendapatkan DAK; Kedua; Kriteria Khusus (KK), yang ditentukan berdasarkan peraturan perundang-undangan yang mengatur penyelenggaraan otonomi khusus dan aspek karakteristik daerah; Ketiga; Kriteria Teknis (KT), yang ditentukan berdasarkan indikatorindikator teknis yang dapat menggambarkan kondisi sarana dan prasarana yang akan didanai dari DAK. Kriteria ini dirumuskan melalui indeks teknis yang disusun oleh Menteri Teknis terkait.

Hasil analisis menunjukkan bahwa tingkat ketergantungan pemerintah daerah Kabupaten Konawe Utara Terhadap Dana Perimbangan masih tinggi yaitu sebesar 21,10\%. Artinya pengeloaan potensi sumberdaya 
perekonomian terutama sumber-sumber pendapatan asli daerah di Kabupaten Konawe Utara belum dikelola secara optimal. Kondisi ini, seiring dengan pendapat yang dikemukakan oleh Syamsi (1999:79) dalam Kaho (2001), bahwa salah satu kriteria penting untuk menunjukkan secara nyata kemampuan keuangan daerah dalam mengatur dan mengurus rumah tangganya, ditunjukkan oleh kemampuan daerah dalam meningkatkan penerimaan daerah secara berkesinambungan seiring dengan perkembangan perekonomian tanpa memperburuk faktor-faktor produksi dan keadilan. Artinya bahwa kemampuan keuangan daerah Kabupaten Konawe Utara belum dapat memenuhi kebutuhan dalam APBD.

Dana Bagi Hasil (DBH) tidak memberikan kontribusi besar terhadap Belanja daerah. Dengan demikian maka belanja daerah lebih didominasi oleh DAU dan DAK dibandingkan dengan DBHP/NP. Hal ini terjadi karena Penyempurnaan mekanisme perhitungan dan penyediaan data DBH Pajak perlu didukung oleh instansi teknis terkait di tingkat pusat maupun daerah agar penerimaan pajak dan DBH lebih optimal. Kebijakan adanya DBH Pajak ini dilatarbelakangi oleh:

1. Kebutuhan pendanaan daerah dalam rangka menyelenggarakan pemerintahan di daerah, tidak seimbang dengan besarnya pendapatan daerah itu sendiri;

2. Keterbatasan kemampuan pemerintah daerah dalam pengumpulan dana secara mandiri;

3. Adanya jenis penerimaan pajak dan atau bukan pajak yang berdasarkan pertimbangan tertentu pemungutannya harus dilaksanakan oleh Pemerintah Pusat, namun obyek dan atau subyek pajaknya berada di daerah;

4. Memperkecil kesenjangan ekonomi antar daerah; memberikan insentif kepada daerah dalam melaksanakan program Pemerintah Pusat;

5. Memberikan kompensasi kepada daerah atas timbulnya beban dari kegiatan yang dilimpahkan oleh Pemerintah Pusat.

Hasil penelitian menunjukkan bahwa DAU memiliki kontribusi terhadap APBD, hal ini dapat diartikan bahwa semakin tinggi DAU yang diterima daerah maka akan semakin tinggi pula belanja modal yang akan dibelanjakan. Adanya kontribusi DAU, dan DAK terhadap Belanja Daerah Kabupaten Konawe Utara yang lebih tinggi daripada kontribusi DBH, atau dengan kata lain belanja daerah lebih didominasi oleh DAU dan DAK dibandingkan dengan DBHP/NP. Hal ini semakin mempertegas pernyataan bahwa respon pemerintah daerah terhadap DAU, dan DAK dalam perencanaan belanja daerah lebih tinggi daripada respon terhadap potensi PAD yang dimiliki atau dapat dinyatakan bahwa telah terjadi flypaper efek dalam Belanja Daerah Kabupaten Konawe Utara. Keadaan ini menggambarkan bahwa pemerintah daerah Kabupaten Konawe Utara lebih focus pada upaya mendapatkan DAU dan DAK daripada upaya meningkatkan PAD yang secara langsung berhubungan terhadap penerimaan bagi hasil (DBH).

Secara empiris penelitian ini membuktikan bahwa besarnya Belanja Daerah dipengaruhi oleh jumlah DAU dan DAK yang diterima dari Pemerintah Pusat dalam artian tingkat ketergantungan Pemerintah Kabupaten Konawe Utara terhadap transfer Pemerintah Pusat masih sangat tinggi. Jika hal ini terus berlangsung maka perkembangan ekonomi daerah kemungkinan besar akan semakin terhambat.

Permasalahan yang perlu dipecahkan agar tingkat ketergantungan ini dapat di eliminir, maka Pemerintah Daerah perlu melakukan langkah-langkah strategis dalam menggali dan memaksimalkan dari potensi Pendapatan Assli Daerah yang dimiliki. Disisi lain efektifitas Belanja Daerah juga perlu menjadi perhatian, karena bukan rahasia umum lagi bagi pemerintah daerah setiap akhir tahun anggaran, terjadi upaya penghabisan anggaran daerah dan Pemerintah Daerah "menunggu" alokasi DAU dan DAK yang akan diperolehnya sebelum menentukan berapa belanja yang akan dihabiskannya.

Kondisi yang demikian memerlukan pengkajian lebih mendalam, baik secara empiris maupun praktik. Misalnya, Pemerintah Daerah harus menyiapkan dan atau merevisi kebijakan terhadap upaya peningkatan 


(C) 1 Jounal publiuho is licensed under a Creative Commons Attribution 4.0 International License, which permits

PAD dan "keharusan" untuk menyusun APBD yang lebih baik dengan menaksir jumlah belanja tahun berjalan, setelah memastikan jumlah penerimaan riil dari pajak dan retribusi daerah.

\section{Strategi Mengatasi Tingkat Ketergantungan Pemerintah Daerah terhadap Dana Perimbangan Pusat}

\section{A. Intensifikasi Peningkatan PAD}

Pola Intensifikasi peningkatan pendapatan dilakukan dengan lebih menekankan pada penerapan nilai atau prinsip-prinsip perpajakan yang baik. Khusus di Kabupaten Konawe Utara Intensifikasi peningkatan PAD dilakukan dengan cara mengoptimalkan sumber-sumber pajak daerah dan retribusi daerah yang sudah ada. Untuk sumber-sumber pajak daerah tersebut berasal dari: Pajak hotel, Pajak restoran, Pajak hiburan, pajak reklame, pajak penerangan jalan, pajak mineral bukan logam dan batuan, pajak parker, pajak biaya perolehan hak atas dan bangunan (BPHTB), dan pajak bumi dan bangunan kabupaten. Dari 9 (Sembilan) Sumber PAD tersebut oleh Pemda senantiasa dari tahun ke tahun dilakukan berbagai penyempurnaan dalam rangka pengoptimalan sumber pajak dalam meningkatan PAD. Penyempurnaan yang dimaksudkan adalah pada penyempurnaan administrasi pendapatan daerah yaitu pada perbaikan sistem pengaturan pemungutan pajak daerah dan retribusi daerah. Hal ini ditujukan agar para wajib pajak daerah dan wajib retribusi daerah dapat secara optimal memenuhi kewajibannya dengan membayar pajak daerah dan retribusi daerah sebagaimana mestinya. Cara yang dilakukan oleh Pemerintah Kabupaten Konawe Utara untuk mewujudkan hal tersebut adalah dengan melakukan: 1) Perbaikan metode identifikasi, mekanisme registrasi dan pemungutan; 2) Mengembangkan sistem evaluasi; 3) Merencanakan dengan lebih baik sistem pengawasan, pemungutan dan pelaporan keuangannya. Upaya peningkatan pajak daerah yang dilakukan oleh Kabupaten Konawe Utara melalui intensifikasi ini belum cukup optimal. Hal ini berdasarkan data yang ditemukan dilapangan dimana, realisasi penerimaan pajak daerah mengalami fluktuatif dan mengalami kecenderungan penurunan setiap tahunnya di sajikan pada Tabel 3.

Tabel 3. Realisasi penerimaan pajak daerah Kabupaten Konawe Utara Tahun 2014-2018.

\begin{tabular}{|c|c|c|c|c|c|c|c|c|c|c|}
\hline \multirow{3}{*}{ Uraian PAD } & \multicolumn{10}{|c|}{ TAHUN } \\
\hline & \multicolumn{2}{|l|}{2014} & \multicolumn{2}{|l|}{2015} & \multicolumn{2}{|l|}{2016} & \multicolumn{2}{|l|}{2017} & \multicolumn{2}{|l|}{2018} \\
\hline & $\mathrm{Rp}$ & $\%$ & $\mathrm{Rp}$ & $\%$ & $\mathrm{Rp}$ & $\%$ & $\mathrm{Rp}$ & $\%$ & $\mathrm{Rp}$ & $\%$ \\
\hline $\begin{array}{l}\text { Pendapatan } \\
\text { Pajak daerah }\end{array}$ & $13,634,000,000$ & 28 & $15,565,000,000$ & 18 & 2,616,184,998 & 6 & $1,032,208,395$ & 5 & $3,796,200,000$ & 15 \\
\hline $\begin{array}{l}\text { Hasil } \\
\text { Retribusi } \\
\text { Daerah }\end{array}$ & $23,709,063,375$ & 49 & $64,824,588,901$ & 74 & $36,630,967,000$ & 84 & $14,538,643,000$ & 63 & $11,612,500,000$ & 45 \\
\hline $\begin{array}{l}\text { Hasil } \\
\text { Pengelolaan } \\
\text { kekayaan } \\
\text { daerah yang } \\
\text { Dipisahkkan }\end{array}$ & - & & $100,000,000$ & 0 & $3,000,000,000$ & 7 & $4,746,606,939$ & 21 & $5,500,000,000$ & 22 \\
\hline $\begin{array}{l}\text { Lain-Lain } \\
\text { Pendapatan } \\
\text { Asli Daerah } \\
\text { yang Sah }\end{array}$ & $10,849,330,671$ & 23 & $7,553,495,607$ & 9 & $1,130,000,000$ & 3 & $2,610,287,854$ & 11 & $4,631,494,869$ & 18 \\
\hline Total PAD & $48,192,394,046$ & 100 & $88,043,084,508$ & 100 & $43,377,151,998$ & 100 & $22,927,746,188$ & 100 & $25,540,194,869$ & 100 \\
\hline
\end{tabular}

Sumber : Dispenda Kab. Konut (diolah), 2018 
Dari tabel diatas menunjukkan bahwa upaya intensifikasi yang dilakukan oleh Kabupaten Konawe Utara melalui peningkatan pajak daerah ini belum mencapai target yang ditetapkan. Dimana dari data di atas menunjukkan bahwa Intensifikasi yang dilakukan Pemerintah Kabupaten Konawe Utara (Tahun 2014/2018) yaitu Pajak hotel, Pajak restoran, Pajak hiburan, Pajak reklame, Pajak penerangan jalan, Pajak mineral bukan logam dan batuan, Pajak parker, Pajak biaya perolehan hak atas dan bangunan (BPHTB), dan Pajak bumi dan bangunan kabupaten semuanya memberikan kontribusi pada peningkatan PAD Kabupaten Konawe Utara.

\section{B. Ekstensifikasi Peningkatan PAD}

Pada pola Ekstensifikasi peningkatan pendapatan pemerintah daerah dilakukan dengan lebih menekankan pada perluasan sumber-sumber pendapatan baru. Kalaupun dilakukan, upaya ekstensifikasi ini hendaknya lebih menekankan pada retribusi daripada yang bersifat pajak.

Khusus di Kabupaten Konawe Utara, Ekstensifikasi telah tampak dilakukan oleh pemerintah, yakni pengembangan potensi daerah terus dilakukan untuk mendapatkan sumber-sumber pendapatan baru bagi Kabupaten Konawe Utara. Ekstensifikasi tersebut yakni memaksimalkan semua potensi sumber-sumber PAD khususnya pada retribusi dari pengembangan pelayanan pasar, retribusi parkir dan retribusi lainnya.

Dari hasil wawancara tersebut menunjukkan bahwa strategi Ekstensifikasi dalam pengembangan PAD yakni dengan memaksimalkan pengelolaan semua potensi sumber-sumber PAD meliputi: 1) Pengelolaan pajak bumi bangunan diadakan pemutakhiran basis data dari tidak ada bangunan menjadi ada,rumah papan menjadi rumah permanen dimana dengan upaya pengelolaan sumber PAD tersebut tentu secara otomatos pajak bumi dan bangunan berubah; 2) pengembangan pajak reklame dengan membuat rangka-rangka reklame dimana rangka ini dapat dipungut pajak setelah disewakan; 3) Pengelolaan pasar-pasar tradisional dan pembangunan lapak-lapak parker dimana lapak bisa disewakan dan parker dapat dipungut retribusinya; 4) Pembuatan lampu-lampu jalan dimana ini dapat dipungut pajak penerangan jalan; dan 5) Penetapan NJOP yang disesuaikan dengan standarisasi harga yang sekarang dimana ini nilai jual tanah akan naik dan dapat dipungut biayanya. Dari upaya tersebut merupakan salah satu penyumbang terbesar bagi peniningkatan retribusi daerah dan ini sebagai upaya untuk peningkatan PAD di Kabupaten Konawe Utara.

Untuk peningkatan pendapatan daerah tersebut melalui program intensifikasi dan ekstensifikasi, pihak Dinas Pendapatan Kabupaten Konawe Utara mempunyai beberapa program kedepan, diantaranya yaitu :

1. Melakukan pendataan Potensi PAD secara efektif. Peluang yang dihadapi oleh Dinas Pendapatan Kabupaten Konawe Utara berupa kebijakan pemerintah UU Nomor 28 Tahun 2009 yang berdimensi keuangan, pertumbuhan ekonomi masyarakat (PDRB dan Incom Perkapita) positif, dan pertambahan potensi PAD yang terus meningkat seiring dengan perkembangan penduduk dengan berbagaikegiatan ekonomi masyarakat yang didukung oleh faktor kekuatan yang secara internal dimiliki oleh Dinas Pendapatan Kabupaten Konawe Utara seperti, Adanya Sistim Komputerisasi Simapada yang dapat mengakses data secara akurat, Pimpinan yang visioner, tersedianya anggaran yang memadai, dan motivasi kerja pegawai yang baik sangat menunjang untuk melakukan strategi kegiatan pendapatan potensi PAD secara efektif sehingga dapat tersedia data base Pajak dan Retribusi Daerah yang akurat.

2. Membangun kerjasama dengan pihak swasta dan masyarakat pemilik hak ulayat dalam pengelolaan/pemunggutan PAD. Peluang lain yang tersedia berupa adanya dukungan pihak eksekutif dan legislatif untuk intensifikasi dan ekstensifikasi PAD, dan adanya kesediaan pihak swasta dan masyarakat untuk melakukan kerjasama dalam pengelolaan/ pemungutan PAD yang didukung dengan kekuatan internal Dinas Pendapatan Kabupaten Konawe Utara berupa pimpinan yang visioner, adanya peraturan daerah sebagai dasar hukum, komitmen pimpinan dan staf untuk mewujudkan misi Dispenda Kabupaten Konawe Utara. 
Jounal publiuho is licensed under a Creative Commons Attribution 4.0 International License, which permits unrestricted use, distribution, and reproduction in any medium, provided the original work is properly cited.

3. Mengintensifkan penyuluhan/sosialisasi berbagai peraturan daerah tentang pajak dan retribusi daerah. Faktor ancaman yang dihadapi oleh Dinas Pendapatan Kabupaten Konawe utara berupa resistensi penolakan terhadap perda pajak dan retribusi dalam rangka ekstensifikasi, rendahnya kesadaran masyarakat dalam membayar pajak dan retribusi daerah yang bila tidak direspon secepatnya akan mempengaruhi kinerja. Maka dengan kekuatan internal berupa adanya anggaran yang memadai, adanya perda sebagai dasar hokum, dan komitmen pimpinan dan staf, dapat dimanfaatkan untuk mendukung pelaksanaan penyuluhan/sosialisasi secara intensif berbagai peraturan daerah yang menyangkut pajak dan retribusi daerah kepada masyarakat sehingga dapat meningkatkan kesadaran Wajib Pajak dan Retribusi dalam memenuhi kewajiban sebagai Warga Negara yang baik.

4. Melakukan penegakan aturan (law enforcement). Faktor eksternal yang dihadapi oleh Dispenda Kabupaten Konawe Utara antara lain berupa kondisi politik yang tidak stabil, dan rendahnya kesadaran masyarakat dalam membayar pajak dan retribusi daerah, dengan peraturan daerah sebagai dasar hukum, komitmen pimpinan dan staf untuk mewujudkan misi, dapat dimanfaatkan untuk melakukan penegakan aturan (law enforcement) yakni dengan memberikan sanksi yang tegas sesuai peraturan yang berlaku baik terhadap pegawai yang melakukan pelanggaran dalam melaksanakan tugas, maupun terhadap masyarakat yang dengan sengaja dan sering melanggar aturan.

5. Meningkatkan Penerimaan. Kelemahan yang dimiliki oleh Dinas Pendapatan Kabupaten Konawe Utara seperti sistim pendataan belum efektif dan kualitas pelayanan belum optimal sehingga kondisi ini harus direspon dan diatasi/dibenahi dengan memanfaatkan peluang yang tersedia yakni UU No 28 Tahun 2009 (01), Dukungan Eksekutif dan legislatif, dan adanya kesempatan mengikuti diklat struktural dan fungsional, akan sangat memungkinkan untuk dilakukan peningkatan kualitas SDM/aparat sehingga akan tersedia SDM aparat yang memiliki kemampuan, keterampilan dan keahlian dalam melaksanakan tugas secara efisien, efektif dan lebih propesional, baik di bidang perencanaan, penyusunan program intensifikasi dan ekstensifikasi PAD dan aplikasi sistem komputer Simapada maupun dalam tugas-tugas pelayanan dibidang pendapatan daerah yang disesuaikan dengan perkembangan dan perubahan lingkungan yang sangat cepat dan dapat merespon aspirasi masyarakat pengguna jasa.

6. Mengoptimalkan Koordinasi. Faktor kelemahan yang dialami oleh Dinas Pendapatan Kabupaten Konawe Utara antara lain berupa pendataan yang tidak efektif, rendahnya kualitas pelayanan dan koordinasi yang tidak optimal yang mana dapat mengganggu kinerja, perlu dibenahi dan dicari jalan pemecahannya dengan memanfaatkan peluang yang ada berupa UU Nomor 28 Tahun 2009 dimana Dukungan Eksekutif dan legislatif dan adanya kesempatan mengikuti diklat struktural dan fungsional melalui suatu Koordinasi yang lebih optimal sehingga lebih mendukung kinerja dalam meningkatkan kinerja dalam pengelolaan PAD dan dapat membangun koordinasi yang lebih optimal dengan instansi terkait sehingga dapat mendukung tugas dan fungsi dalam meningkatkan PAD.

7. Melakukan Pengadaan Sarana dan Prasarana Kerja. Faktor kelemahan lain yang dialami oleh Dinas Pendapatan Kabupaten Konawe Utara berupa sarana dan prasarana kerja yang tidak memadai dan rendahnya kualitas pelayanan perlu direspon segera guna meningkatkan kineria dengan memanfaatkan peluang yang ada berupa UU Nomor 28 Tahun 2009, dukungan eksekutif dan legislatif akan sangat mendukung untuk melakukan pengadaan sarana dan prasarana kerja dalam rangka meningkatkan kinerja dalam pengelolaan PAD. 


\section{KESIMPULAN}

Berdasarkan uraian dan pembahasan di atas maka penulis menarik simpulan penelitian bahwa

1. Perkembangan Dana Perimbangan dari Pemerintah Pusat selama periode tahun 2014-2014 adalah sebesar Rp. 2,674,553,632,408, dengan rata-rata Dana Perimbangan sebesar Rp. 445,758,938,734 pertahun

2. Tingkat ketergantungan daerah terhadap dana perimbangan yang terdiri atas Dana Bagi Hasil (DBH), Dana Alokasi Umum (DAU) dan Dana Alokasi Khusus (DAK) adalah sebesar 78,90 \%, yang menandakan bahwa dana perimbangan memberikan kontribusi yang cukup tinggi terhadap pendapatan daerah Kabupaten Konawe Utara. Artinya bahwa tingkat ketergantungan pemerintah daeraha terhadap dana perimbangan masih cukup tinggi dimana angka tersebut dapat dikurangi dengan mengoptimalkan sumber - sumber pendapatan yang lain.

3. Strategi Pemerintah Daerah Kabupaten Konawe Utara dalam upaya mangatasi tingkat ketergantungan terhadap dana perimbangan dalam menunjang APBD yaitu dilakukan dengan 2 (dua) pola: 1) Intensifikasi yaitu Pemerintah Daerah Kabupaten Konawe Utara melakukan pengoptimalisasian Pendapatan Asli Daerah (PAD) dengan cara mengoptimalkan sumber-sumber pajak daerah dan retribusi daerah yang sudah ada; 2) Ekstensifikasi yaitu mangatasi tingkat ketergantungan terhadap dana perimbangan dengan peningkatan pendapatan Daerah Kabupaten Konawe Utara dengan lebih menekankan pada perluasaan sumber-sumber pendapatan baru, yakni dengan melakukan mengembangan retribusi pada retribusi dari pengembangan pelayanan pasar, retribusi parkir dan retribusi lainnya.

\section{SARAN}

Berdasarkan kesimpulan dari hasil penelitian ini, maka disarankan kepada pemerintah daerah Kabupaten Konawe Utara agar implementasi kebijakan dalam penelitian ini dapat diterapkan sehingga potensi sumbersumber Pendapatan Asli Daerah yang dimiliki dapat bernilai ekonomis bagi pelaksanaan pembangunan daerah dan bagi peneliti selanjutnya, agar variabel penelitian ini lebih diperluas terutama berkaitan dengan investasi daerah dan pengaruhnya terhadap Pendapatan Asli Daerah. 
CC Jounal publiuho is licensed under a Creative Commons Attribution 4.0 International License, which permits

\section{DAFTAR PUSTAKA}

Creswell, Jhon W. 1994. Research Design Qualitative and Quantitative Approaches. Thousand Oaks, London, New Delhi : Sage.

Halim, Abd. 2002 Pemerintahan Daerah, Jakarta, Bina Aksara.

Moleong J, Lexi, 2000. Metodologi Penelitian Kualitatif. Remaja Rosdakarya, Jakarta.

Mulyana, Dedy. 2001. Metodologi Penelitian Kualitatif , Paradigma Baru Ilmu Komunikasi dan Ilmu Sosial lainnya, Bandung: Rosdakarya.

Nasution S, 1992. "Metodologi Penelitian Naturalistik Kualitatif", Bandung, Tarsito.

Sugiyono, 2006, Metode Penelitian Administrasi, Bandung, Alfabeta.

Sutopo. 1999. Pelayanan Prima. Jakarta, Lembaga Administrasi Negara.

Undang-Undang No. 33 Tahun 2004 tentang Perimbangan Keuangan Pusat dan Daerah

Undang Undang No. 28 Tahun 2009 tentang Pajak Daerah dan Retribusi Daerah

Peraturan Pemerintah Nomor 45 Tahun 2003 tentang Tarif Atas Jenis Penerimaan Negara Bukan Pajak Yang Berlaku Pada Departemen ESDM. 